\title{
A Little Fish with a High Heavy Metals Burden: The Case of Straightfin Barb, Enteromius paludinosus (Peters 1852) from River Malewa, Naivasha, Kenya
}

Elizabeth Adhiambo Ngesa, Elick Onyango Otachi and Nzula Kivuva Kitaka

Department of Biological Sciences, Egerton University, PO Box 536, Egerton, Kenya

\begin{abstract}
This paper addresses the accumulation of heavy metals namely; Arsenic (As), Chromium $(\mathrm{Cr})$, Lead $(\mathrm{Pb})$ and Mercury $(\mathrm{Hg})$ in the tissues of Straightfin barb, Enteromius paludinosus (Peters 1852) from the mouth of River Malewa in Lake Naivasha, Kenya. A total of 1307 fish were collected from the lake during the month of November, 2017. Water samples, sediment samples, 25 fish muscle tissues and its endoparasite, the cestode Ligula intestinalis were collected and heavy metal concentrations determined using the Thermal-electron atomic absorption spectrophotometer. The concentrations of these heavy metals in the sediment showed no signs of pollution. In the muscle tissues of the fish, $\mathrm{As}, \mathrm{Cr}, \mathrm{Pb}$ and $\mathrm{Hg}$ showed high levels with mean concentrations of 5.0696, 22.0854, 45.2108 and $1.5458 \mathrm{mg} /$ $\mathrm{kg}$ ww respectively. The Target hazard quotients of $\mathrm{As}, \mathrm{Cr}, \mathrm{Pb}$ and $\mathrm{Hg}$ obtained were 98.5066, 42.9138, 65.8863 and 90.1086 respectively, indicating a possible health risk associated with the consumption of the straightfin barb. The bioaccumulation factors for $L$. intestinalis were $2.4093,2.1873,5.8601$ and 5.1395 for $\mathrm{As}, \mathrm{Cr}, \mathrm{Pb}$ and $\mathrm{Hg}$, respectively, indicating the potential of the cestode in accumulation of heavy metals from the host inferring that these parasites can be used as an accumulation bioindicator instead of its host fish because of its better heavy metal accumulation potential.
\end{abstract}

Keywords: Heavy metals; Enteromius paludinosus; Lake Naivasha; Target hazard quotient (THQ); Ligula intestinalis; Bioaccumulation factor (BAF)

\section{Introduction}

Trace elements including heavy metals are natural components of aquatic ecosystems but usually occur in low concentrations [1]. They mainly get into the water bodies through the natural geological weathering of rocks and soil, directly exposed to surface waters. Additionally, heavy metals get into the aquatic environment through anthropogenic activities such as domestic, industrial, mining, and agricultural activities leading to contamination. When they get into the aquatic environment, they get adsorbed onto inorganic and organic particulate deposits and are incorporated into sediment resulting in elevated levels in the bottom sediment area [2]. Elevated levels of heavy metals in the aquatic environment can affect aquatic organisms especially when they occur above threshold concentrations [1]. Some heavy metals bioaccumulate in various organs of aquatic organisms $[3,4]$. Some of the reported toxic effects of heavy metals in aquatic organisms include; tissue damage, disruption in growth, reproduction, induction and synthesis of metallothionein [5].

When aquatic organisms such as fish are exposed to elevated metal levels, they can absorb the bioavailable metals from their environment directly via the gills and skin or through the ingestion of contaminated water and food. These metals are then transported by the bloodstream bringing them into contact with the various organs and tissues [6]. However, there is a certain extent to which fish can regulate metal concentrations beyond which bioaccumulation will take place. When such fish are consumed by human beings, they pose a risk to their health and can eventually cause death. In a report of the world's worst pollution problems, heavy metals are said to have the most potential risk to the health of large human population hence, they are a top threat to humankind [7]. It is because of such potential risks that several studies on heavy metals have been carried out in various aquatic water bodies in Kenya. For example, in Lake Naivasha, despite being a Ramsar site and a world heritage site, its perceived to be heavily impacted by anthropogenic activities, resulting to a number of investigations on heavy metals $[1,3,8,9]$.

These studies have found elevated levels of some heavy metals such as Aluminium ( $\mathrm{Al})$, Iron $(\mathrm{Fe})$, Manganese $(\mathrm{Mn})$, Zinc $(\mathrm{Zn})$, Rubidium $(\mathrm{Rb})$, Copper $(\mathrm{Cu})$, Cadmium $(\mathrm{Cd})$ and Lead $(\mathrm{Pb})$ in the sediments compared to the threshold levels provided by Turekian et al. [10] and in fish as compared to the recommended levels by FAO [11]. For example, Mutia et al. [8] reported that the concentration levels of $\mathrm{Pb}$ and $\mathrm{Cd}$ in edible muscle of the Common carp (Cyprinus carpio) from Lake Naivasha were above the maximum allowable FAO limits which is 0.3 $\mathrm{mg} / \mathrm{kg}$ for edible portions of fish. On the other hand, Otachi et al. [3] reported high Target Hazard Quotients (THQ) of Li, $\mathrm{Zn}, \mathrm{Sr}$ and $\mathrm{Cd}$ in the muscle of Oreochromis leucostictus from the lake indicating a health risk to the local community that depends on fish for regular food

Although some research has been done to correlate several heavy metal concentrations in sediments, water and fish in different sites around Lake Naivasha $[3,8]$, none of the studies has included $\mathrm{Hg}$, As and $\mathrm{Cr}$ in their studies. Furthermore, there are no studies that have correlated the heavy metals concentrations in the sediment and water from Lake Naivasha with the Straightfin barb (E. paludinosus), a fish species that hosts a parasite (Ligula intestinalis), the latter having high ability to absorb heavy metals from its host. Enteromius paludinosus

*Corresponding author: Otachi EO, Department of Biological Sciences, Egerton University, PO Box 536, Egerton, Kenya, Tel: +22545430555; E-mail: elickotachi@gmail.com

Received May 08, 2018; Accepted July 01, 2018; Published July 05, 2018

Citation: Ngesa EA, Otachi EO, Kitaka NK (2018) Department of Biological Sciences, Egerton University, PO Box 536, Egerton, Kenya. J Environ Anal Toxicol 8: 583. doi: 10.4172/2161-0525.1000583

Copyright: @ $2018 \mathrm{Ngesa}$ EA, et al. This is an open-access article distributed under the terms of the Creative Commons Attribution License, which permits unrestricted use, distribution, and reproduction in any medium, provided the original author and source are credited. 
Citation: Ngesa EA, Otachi EO, Kitaka NK (2018) A Little Fish with a High Heavy Metals Burden: The Case of Straightfin Barb, Enteromius paludinosus (Peters 1852) from River Malewa, Naivasha, Kenya. J Environ Anal Toxicol 8: 583. doi: 10.4172/2161-0525.1000583

Page 2 of 7

is a little fish (maximum size $15 \mathrm{~cm}$ Standard Length), which is a benthopelagic species and occupies a range of habitats including large rivers, lagoons both connected or isolated from main river channels, and small and large streams [12]. It is a subsistence source of proteins mainly for artisanal fishers and their dependents in the area, but rarely featuring in the fish markets around the lake. The aim of this study was to determine the concentrations of $\mathrm{THg}, \mathrm{Pb}, \mathrm{Cr}$ and As in the fish tissues and associated parasites of E. paludinosus from Lake Naivasha, Kenya, and assess potential health risks for fish consumers around Lake Naivasha.

\section{Materials and Methods}

\section{Study area}

Sampling was undertaken at Lake Naivasha in the month of November 2017. Lake Naivasha is a shallow freshwater lake in the Great Rift Valley of Kenya. Its freshness is attributed to surface water inflow, biogeochemical sedimentation and underground seepage [13]. The lake has a surface area that ranges between 120 and $150 \mathrm{~km}^{2}$ subject to the dry and wet seasons respectively, with a mean depth of 4-6 $\mathrm{m}[14,15]$. The lake is located at an altitude of $1885 \mathrm{~m}$ a.s.l between latitude $00^{\circ} 45^{\prime}$ S- $00^{\circ} 53^{\prime} \mathrm{S}$ and longitude $36^{\circ} 15^{\prime} \mathrm{E}-36^{\circ} 30^{\prime} \mathrm{E}$ [16]. Lake Naivasha is a eutrophic lake [17] and most of its freshwater inflow comes from River Malewa [18]. In the year 1995, Lake Naivasha was declared a Ramsar Site giving it an international importance due to its freshness and diverse ecology [19]. The mean temperature of the lake is approximately $25^{\circ} \mathrm{C}$, with a maximum temperature of $30^{\circ} \mathrm{C}$ [20]. Its mean annual rainfall ranges from about $60 \mathrm{~mm}$ at the Naivasha township to some $170 \mathrm{~mm}$ along the slopes of the Nyandarua mountains, with open water evaporation estimated at approximately $172 \mathrm{~cm} /$ year [21]. The main activities that depend on the use of water from this lake include agriculture (horticultural farms), geothermal power generation, domestic water supply, commercial fishing, tourism, and recreation including ranching and game farming. This consequently results to environmental problems such as water abstraction, which results to changes in water level, eutrophication, pollution, and invasive species, and also decline in fish stocks and biodiversity [22]. Figure 1 shows the location of the sampling site; the mouth of River Malewa $\left(0.714622^{\circ} \mathrm{S}\right.$ $\left.36.362709^{\circ} \mathrm{E}\right)$.

\section{Water and sediment sampling}

Measurements of the $\mathrm{pH}$, dissolved oxygen, conductivity and temperature were taken in situ $10 \mathrm{~cm}$ below the water surface from the selected sampling site using a Multi probe water quality meter (Model Multi HQ40d, USA). $500 \mathrm{ml}$ of water sample was collected from the same depth by immersing the bottle and lifting it up and immediately filtered using a filter pump fitted with Whatman GFC filters into a plastic bottle and acidified with $2.5 \mathrm{ml}$ of concentrated nitric acid (Analytical grade) to avoid precipitation of the metals and adsorption at the surface of the bottles. A sediment sample was then obtained using stainless Ekman grab sampler. The sediment sample taken for heavy metal analysis was obtained from the sample that was not in contact with the metallic surfaces of the Ekman grab sampler to avoid contamination. The sample was then put in a plastic sample vial which was then placed inside a cool box and transported to a laboratory at the Biological Sciences Department, Egerton University. The water and sediment samples were then stored in the refrigerator at a temperature of $-20^{\circ} \mathrm{C}$ in the laboratory and later transported to the Lake Nakuru Water Quality Testing Laboratory (WQTL) for heavy metal determination after three days.

\section{Fish sampling and parasitological examination}

A total of 1307 fish samples were collected using seine nets of mesh size $1.2 \mathrm{~mm}$ from the mouth of River Malewa. The fish were caught by the fishermen then placed in aerated water tanks. They were then transported to Biological Sciences Department, Egerton University laboratory. In the laboratory, the fish were killed humanely by cervical dislocation. This was then followed by measurements of the total lengths (TL) in $\mathrm{cm}$ using a measuring board. The weight of the fish was then measured in $\mathrm{g}$ using an electronic weighing scale (Model ED 4202S, Sartorius AG, Germany). The fish were varying in length and weight. Dissection was then done following standard procedures in parasitological analyses [23]. Where found, the cestode Ligula intestinalis was collected from the body cavity of the fish using plastic forceps. The parasites were thoroughly rinsed with double distilled water and placed in plastic vials then stored in the refrigerator at a temperature of $-20^{\circ} \mathrm{C}$ for heavy metal determination. This was followed by obtaining the fish tissues $(0.2 \mathrm{~g})$ using a ceramic knife and plastic tweezers, washed with double distilled water and then stored in the refrigerator for heavy metal determination. An image of $L$. intestinalis and its host E. paludinosus is shown in Figure 2.

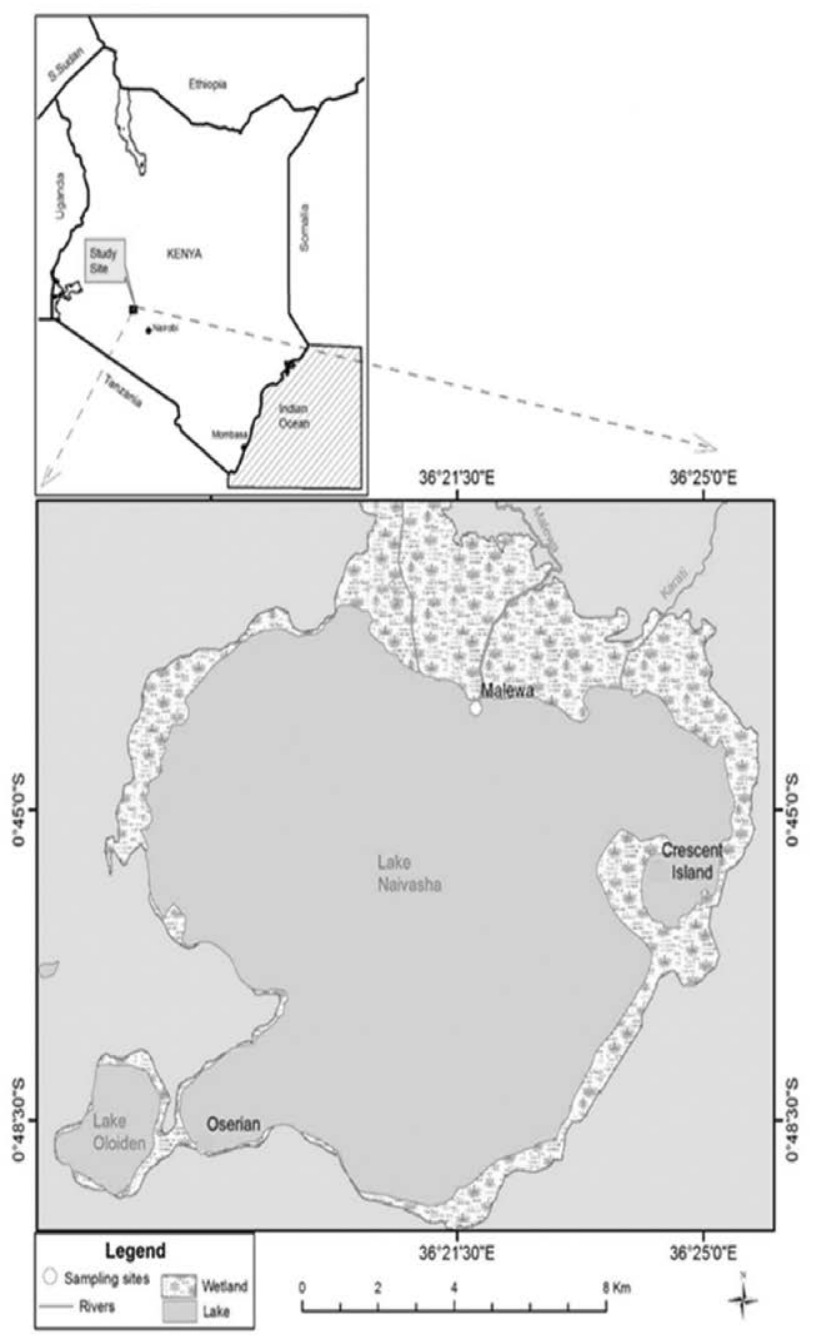

Figure 1: Map of Lake Naivasha showing the sampling site. 
Citation: Ngesa EA, Otachi EO, Kitaka NK (2018) A Little Fish with a High Heavy Metals Burden: The Case of Straightfin Barb, Enteromius paludinosus (Peters 1852) from River Malewa, Naivasha, Kenya. J Environ Anal Toxicol 8: 583. doi: 10.4172/2161-0525.1000583

Page 3 of 7

\section{Heavy metal determinations in water, sediment, fi h muscle tissues and the parasites}

The water, sediment, 25 fish muscle tissues of fish (5 infected with $L$. intestinalis and 20 non-infected) and 5 samples of $L$. intestinalis were transported to Lake Nakuru Water Quality Testing Laboratory (WQTL) for heavy metals analysis. According to APHA [24] standard method, $100 \mathrm{ml}$ of the water sample was measured using a clean measuring cylinder and poured into a clean beaker. The sample was then digested with $5 \mathrm{ml} \mathrm{69 \%}$ concentrated nitric acid (Analytical grade) and then diluted with $50 \mathrm{ml}$ of distilled water followed by heating on a hot plate stirrer at $440^{\circ} \mathrm{C}$ in a fume hood for one hour until the volume was reduced to approximately $25 \mathrm{ml}$. The sample was then allowed to cool. After cooling, it was filtered to a final volume of $100 \mathrm{ml}$ using Whatman $150 \mathrm{~mm}$ dia No.41 filter paper by washing out with distilled water, into $100 \mathrm{ml}$ volumetric flask ready for heavy analysis. The sediment sample was homogenized with mortar and pestle before processing then $2 \mathrm{~g}$ weighed which was digested and diluted the same way as the water sample. The same procedure was also followed for the fish tissues $(0.2$ g) and parasites $(0.1 \mathrm{~g})$. The processed samples (of water, sediment, fis muscle tissues and the cestode) in the $100 \mathrm{ml}$ volumetric flasks were then taken to the Thermal-electron atomic absorption spectrophotometer (AAS- S series, United Kingdom) for heavy metal analysis. The concentrations of the metals were determined in triplicates in order to check the accuracy of the instrument. A standard and a blank sample were run after every five samples to check instrumental drift. Standar were prepared for instrument calibration by serial dilution of a working solution $(100 \mathrm{mg} / \mathrm{L})$ prepared from analytical grade stock solutions $(1,000 \mathrm{mg} / \mathrm{L})$ obtained from Merck KGaA, Germany. The calibration curve method was used to quantify the heavy metal concentrations. In order to get the recovery rates for each heavy metal, one extra sample from the water, sediment, fish muscle tissue and parasite was spiked. The recovery rates shown were $96 \%$ for As, $105 \%$ for $\mathrm{Hg}$, $98 \%$ for $\mathrm{Cr}$ and $99 \%$ for $\mathrm{Pb}$ which were all within the recommended range.

\section{Bioconcentration and bioaccumulation factors}

Bioconcentration factors (BCF) were calculated to determine the ratio in element concentrations between fish and environment (water and sediment) according to the method by Otachi et al. [25]. The BCF was calculated using the mean concentration values of each of the elements present in the fish muscle, water and sediment. The BCF calculations were also used to determine the partitioning of elements between different samples. The BCF was calculated as follow

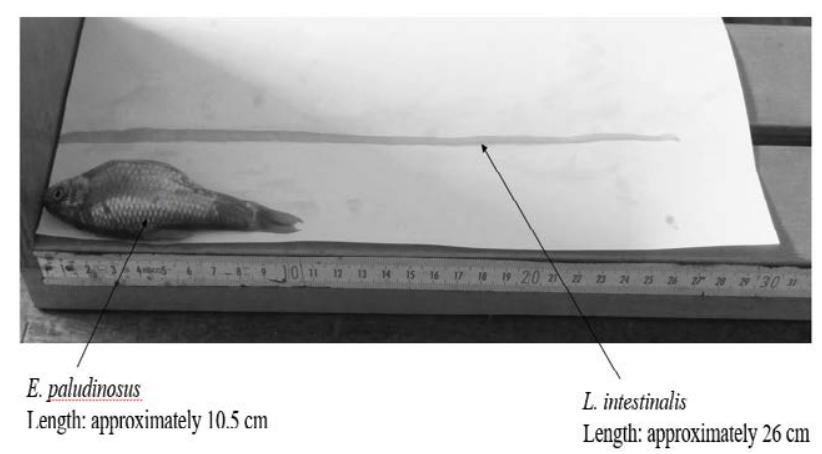

Figure 2: Photograph of E. paludinosus alongside its endoparasite, $L$. intestinalis.

$$
\begin{aligned}
& \mathrm{BCF}=\mathrm{C}(\text { fish muscle }) / \mathrm{C} \text { (water) } \\
& \mathrm{BCF}=\mathrm{C} \text { (fish muscle) } / \mathrm{C} \text { (sediment) }
\end{aligned}
$$

Where, $\mathrm{C}$ stands for mean concentration. C (fish organ) and C (sediment) are measured in ( $\mathrm{mg} / \mathrm{kg}$ wet weight) while $\mathrm{C}$ (water) is measured in $(\mathrm{mg} / \mathrm{l})$.

The bioaccumulation factors (BAF) were determined using the formula by Drexler et al. [26] which is calculated as follows:

$\operatorname{BAF}(x, y)=$ Concentration of trace element in $x /$ concentration of trace element in $\mathrm{y}$

Where by, the variables $\mathrm{x}$ and $\mathrm{y}$ stand for matrices that are compared to each other, in this case, parasites ( $\mathrm{x}$ ) and fish muscle $(\mathrm{y})$

\section{Risk assessment}

In order to assess the risk brought about by the heavy metals to people who consume E. paludinosus in the area, the target hazard quotients (THQ) was determined for heavy metals. THQ is the ratio between the potential exposure to a substance and the reference dose, that is the level at which no adverse effects are expected [27]. A THQ that results to $\leq 1$ indicates no significant risk to the health of fish consumers whereas that which is $>1$ indicates a possible health risk associated with the consumption of the respective metals within the fish muscle. In addition to that, a THQ of 0.1 was later suggested for noncarcinogens to account for additive effects [27]. The equation for determining THQ according to USEPA [27] is:

\section{$\mathrm{THQ}=\mathrm{EFr} \times \mathrm{EDr} \times \mathrm{IRFa} \times \mathrm{C} / \mathrm{RfDo} \times \mathrm{Bwa} \times \mathrm{AT}$}

Where; EFr is the exposure frequency (350 days/year), EDr is the exposure duration (30 years), IRFa is the fish consumption per day $(0.0123 \mathrm{~kg} /$ day) since the per capita is $4.5 \mathrm{~kg} /$ year in Kenya [28], C is the metal concentration in the edible portion of fish (milligrams per kilogram wet weight (ww), RfDo is the reference dose, oral (milligrams per kilogram per day, according to the updated 2017 Regional Screening Level (RSL) in the fish ingestion table [29], BWa is the body weight, adult $60.7 \mathrm{~kg}$, for Kenya [30], and AT is the averaging time for noncarcinogens (365 days/year). The mean concentrations of heavy metals were additionally compared with FAO/WHO and EU recommended values.

\section{Data analysis}

Theheavy metals concentrations in various matrices are presented as arithmetic mean with standard deviation (mean \pm standard deviation). The differences in mean concentrations of heavy metals between the fish and the parasite was tested using a t-test.

\section{Results}

\section{Physico-chemical parameters}

The physico-chemical parameters recorded on the sampling date for temperature $\left({ }^{\circ} \mathrm{C}\right), \mathrm{pH}$, dissolved oxygen $(\mathrm{mg} / \mathrm{L})$, dissolved oxygen saturation (\% sat) and conductivity $(\mu \mathrm{S} / \mathrm{cm})$ were $18.16,7.9,7.93,106.2$ and 129.44 respectively.

\section{Heavy metal concentrations in water and sediment}

Among the four heavy metals measured, two (As and Cr) were below detection in the water sample as indicated in Table $1 . \mathrm{Pb}$ was highest in concentration in both the water and sediment. $\mathrm{Pb}$ was also high in water than $\mathrm{Hg}$ (Table 1), while in the sediment the order was $\mathrm{Pb}>\mathrm{Cr}>\mathrm{As}>\mathrm{Hg}$ (Table 2). 
Citation: Ngesa EA, Otachi EO, Kitaka NK (2018) A Little Fish with a High Heavy Metals Burden: The Case of Straightfin Barb, Enteromius paludinosus (Peters 1852) from River Malewa, Naivasha, Kenya. J Environ Anal Toxicol 8: 583. doi: 10.4172/2161-0525.1000583

Page 4 of 7

\begin{tabular}{|c|c|c|c|c|c|c|c|}
\hline Element & Water $(\mathbf{m g} / \mathbf{l})$ & LLD & WHO limits(mg/l) & KEBS (mg/l) & Elementaita & Nakuru & Bogoria \\
\hline $\mathrm{As}$ & $\mathrm{BD}$ & 0.001 & 0.01 & 0.01 & 0.0227 \\
\hline $\mathrm{Cr}$ & $\mathrm{BD}$ & 0.01 & 0.05 & 0.05 & 0.00608 \\
\hline $\mathrm{Pb}$ & 0.076 & 0.004 & 0.01 & 0.01 & N. D & 0.00125 \\
\hline $\mathrm{Hg}$ & 0.001 & 0.0005 & - & 0.001 & 0.00021 \\
\hline
\end{tabular}

B.D: Below detection limit, N.D: Not Detected WHO: World Health Organization [33], KEBS: Kenya Bureau of Standards [50].

Table 1: Heavy metal concentrations for water samples (with lowest limits of detection -LLD) and comparison with the WHO and KEBS limits in comparison with other Rift Valley Lakes [9].

\section{Heavy metal concentrations in E. paludinosus}

A total of 1307 E. paludinosus were measured obtaining a mean length ( \pm Standard Deviation) of $8.4804 \pm 1.0407$ and a mean weight of $6.2339 \pm 2.4044$ with a mean condition factor of $0.9727 \pm 0.1497$ indicating that the fish were not in a good condition $(\mathrm{k}<1)$. In the fish muscle sample, $\mathrm{Pb}$ had the highest concentration. The order of heavy metal concentration in the muscle of E. paludinosus was $\mathrm{Pb}>\mathrm{Cr}>\mathrm{As}>\mathrm{Hg}$ (Table 3).

\section{Target hazard quotients}

Arsenic (As) had the highest THQ value followed by $\mathrm{Hg}$ then $\mathrm{Pb}$ while $\mathrm{Cr}$ had the least. The THQ values are shown in Table 4

\section{Bioconcentration factors}

Calculation of BCF values (Table 5) for heavy metals in water and sediment compared with tissues of E. paludinosus indicate that $\mathrm{Pb}$ and $\mathrm{Hg}$ levels were present in higher concentrations in the fish tissues compared to the water $(\mathrm{BCF}>1)$. Bioconcentration factors $(\mathrm{BCF})$ could not be determined for As and $\mathrm{Cr}$ in water as these elements were below the detection limits of the instrumentation. $\mathrm{As}, \mathrm{Cr}, \mathrm{Pb}$ and $\mathrm{Hg}$ levels were also present in higher concentrations in the fish tissues compared to the sediment.

\section{Bioaccumulation factors for heavy metals in E. paludinosus}

Out of the 1307 fish sampled, only 5 were infected by the parasite (prevalence $=0.4 \%$ ), L. intestinalis with only 1 cestode recorded per infected fish giving a low parasite prevalence of 5 out of 1307 examined individuals infected. L. intestinalis contained systematically higher concentration of all the heavy metals than the host fish obtaining mean concentration $(\mathrm{mg} / \mathrm{kg})$ values of $3.54232,38.0532,7.797$ and 1.59152 for $\mathrm{Hg}, \mathrm{Pb}, \mathrm{Cr}$ and As respectively against the mean concentrations in the host tissues with values of $0.68924,6.4936,3.5646$ and 0.66058 for the same respectively. All the four heavy metals showed BAF values $>1$ (Figure 3). There were significant differences between the mean concentrations of the four heavy metals analyzed between the host and the parasite ( $\mathrm{t}$-test, $\mathrm{p}$ values $<0.05)$.

\section{Discussion}

\section{Physico-chemical parameters of water}

The values of physico-chemical parameters obtained during the study were in agreement with those obtained by Otachi et al. [3] and Mutia et al. [8] except for the $\mathrm{pH}$ and conductivity which were lower than that of our study. This could be attributed to the rainy season at the time of sampling as well as the location of the study site where River Malewa empties its waters into the lake. The value of $\mathrm{pH}$ for this study was similar to that of Wanjau et al. [31,32] in Lake Naivasha. However, Ogendi et al. [32] reported lower values for conductivity and dissolved oxygen.

\section{Trace element concentrations in water}

Water sample analysis revealed that most elements were present in lower concentrations compared to those in the sediment and the fish muscle tissue. The $\mathrm{Pb}$ levels were however lower than those reported by Ogendi et al. [8] who recorded $0.17983 \mathrm{mg} / \mathrm{L}$ from the same lake. Ochieng et al. [1,9] on the other hand reported lower $\mathrm{Pb}$ concentrations of 0.0421 and $0.00016 \mathrm{mg} / \mathrm{L}$ respectively in the same lake. The high levels of $\mathrm{Pb}$ at the sampling point could be an indication that $\mathrm{Pb}$ is coming in from upstream through runoff. Other sources of $\mathrm{Pb}$ could be from anthropogenic activities such as farming as well as other particulates from natural sources. The comparison of concentrations of the heavy metals in water in Lake Naivasha with the Kenyan and WHO/FAO acceptable standards revealed that the $\mathrm{Pb}$ concentration in water was higher than that of as well as the WHO [33] maximum permissible level in drinking water. This is an indication that the lake may be polluted with $\mathrm{Pb}$. In this study, As and $\mathrm{Cr}$ were below the detection limit of instrumentation hence below the WHO/FAO and KEBS standards contrary to the findings of Yang et al. [9] who reported for other Kenyan rift valley lakes. He reported levels of As: $0.0227,0.00608$ and $0.00125 \mathrm{mg} / \mathrm{L}$ in Lakes Elementaita, Nakuru and Bogoria. Cr on the other hand was detected in Lake Elementaita while it was below detection limit in Lakes Nakuru and Bogoria as well as in Lake Naivasha during this study. The Hg levels were within the KEBS drinking water limits. The $\mathrm{Pb}$ levels reported for Lake Naivasha in this study were higher than that of Lakes Elementaita, Nakuru and Bogoria by Yang et al. [9].

\section{Trace elements concentrations in sediments}

The heavy metal levels obtained during this study were compared with the LEL, TEC, SEL and Shale values as shown in Table 2. The Pb levels were lower than those reported by Mutia et al. [8] but higher than those reported by Otachi et al. [3] in the same lake. High Pb levels reported in the sediment samples could be as a result of contamination from the catchment. $\mathrm{Cr}$ values recorded were higher than those reported by Ochieng et al. [1]. To the best of our knowledge, this is the first report of As and $\mathrm{Hg}$ in the sediment of this lake. All the four heavy metals had concentrations of below the LEL, TEC, SEL and the Shale values of sedimentary rocks (considered to be the normal background level in the Earth's crust) [10] and therefore showing no sign of pollution.

\section{Trace element concentrations in E. paludinosus muscle tissues}

Each of the four heavy metals concentration in the fish muscle tissue is as discussed briefly below

Pb: $\mathrm{Pb}$ was the highest in concentration in the fish muscle tissue compared to the other three heavy metals (As, $\mathrm{Cr}$ and $\mathrm{Hg}$ ). The $\mathrm{Pb}$ levels in the muscle tissue of E. paludinosus obtained in this study were lower than those of Mutia et al. [8] in the common carp (Cyprinus carpio) from Lake Naivasha, with a mean concentration $( \pm S D)$ of $58.11 \pm 0.050 \mathrm{mg} / \mathrm{kg}$ ww (wet weight). However, Wanjau et al. [31,32] 
Citation: Ngesa EA, Otachi EO, Kitaka NK (2018) A Little Fish with a High Heavy Metals Burden: The Case of Straightfin Barb, Enteromius paludinosus (Peters 1852) from River Malewa, Naivasha, Kenya. J Environ Anal Toxicol 8: 583. doi: 10.4172/2161-0525.1000583

\begin{tabular}{|c|c|c|c|c|c|}
\hline Element & Sediment $\mathbf{( m g / k g )}$ & LEL & TEC & SEL & Shale \\
\hline $\mathrm{As}$ & 0.171 & 6.0 & 9.79 & 33.0 & 13 \\
\hline $\mathrm{Cr}$ & 1.49 & 26.0 & 43.4 & 110.0 & 90 \\
\hline $\mathrm{Pb}$ & 15.82 & 31.0 & 35.8 & 250.0 & 20 \\
\hline $\mathrm{Hg}$ & 0.054 & 0.2 & 0.18 & 2.0 & - \\
\hline
\end{tabular}

LEL: lowest effect level in sediment, TEC: threshold effect concentration in sediment, SEL: severe effect concentration in sediment [51].

Table 2: Heavy metal concentrations for sediment samples in comparison with Sediment Quality Guidelines.

\begin{tabular}{|c|c|c|c|}
\hline Element & E. paludinosus & FAO/WHO & EU \\
\hline $\mathrm{As}$ & $5.07 \pm 2.74$ & - & - \\
\hline $\mathrm{Cr}$ & $22.09 \pm 17.90$ & - & - \\
\hline $\mathrm{Pb}$ & $45.21 \pm 29.45$ & 0.3 & 0.3 \\
\hline $\mathrm{Hg}$ & $1.55 \pm 1.80$ & 0.5 & 0.5 \\
\hline
\end{tabular}

Food and Agriculture Organization (FAO)/World Health Organization (WHO) [11]; European Union (EU) [34]

Table 3: Trace element concentrations in the muscle of $E$. paludinosus fish in Lake Naivasha: values are means (mg/kg wet weight) compared with $\mathrm{FAO} / \mathrm{WHO}$ and EU standards $(n=20)$.

\begin{tabular}{|c|c|c|c|c|}
\hline & As & $\mathbf{C r}$ & $\mathbf{P b}$ & $\mathbf{H g}$ \\
\hline RfDo & 0.0003 & 0.003 & 0.004 & 0.0001 \\
\hline THQ & 98.5066 & 42.9138 & 65.8863 & 90.1086 \\
\hline
\end{tabular}

Table 4: Target hazard quotients (THQ) for the four heavy metals in E. paludinosus fish from Lake Naivasha (RfDo, reference dose, oral according to USEPA [29]

\begin{tabular}{|c|c|c|}
\hline Element & Fish/Water & Fish/Sediment \\
\hline As & N. D & 29.65 \\
\hline $\mathbf{C r}$ & N. D & 14.82 \\
\hline $\mathbf{P b}$ & 1.27 & 2.86 \\
\hline $\mathbf{H g}$ & 2.96 & 28.63 \\
\hline
\end{tabular}

N.D.: <Detection limit

Table 5: BCF values calculated between mean trace element concentrations in water and sediment and compared to E. paludinosus muscles from Lake Naivasha.

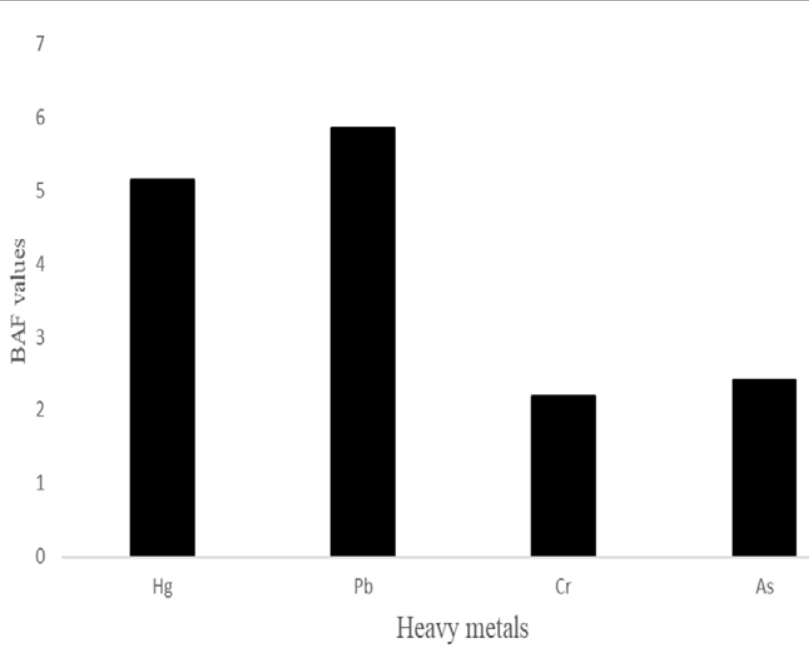

Figure 3: Bioaccumulation factors (BAF) for heavy metals in L. intestinalis vs fish muscle tissue $(n=5)$

recorded lower $\mathrm{Pb}$ levels in various fish from Lake Naivasha. For example, Ogendi et al. [32] reported $0.073 \pm 0.002 \mathrm{mg} / \mathrm{kg}$ ww in $C$. carpio while Wanjau et al. [31] reported $1.49,1.56,1.51$ and $3.22 \mathrm{mg} / \mathrm{kg}$ ww in Oreochromis leucostictus, C. carpio, and Micropterus salmoides respectively. However, the $\mathrm{Pb}$ levels reported in this study were above both the WHO/FAO and EU [34] maximum permissible level and therefore not safe for human consumption as it can cause neurological damage, anemia, nerve disorders, and a number of other health problems [8]. The THQ value of $\mathrm{Pb}$ was 65.8863 which was very high thus a health risk to the consumers of this fish from Lake Naivasha

Cr: The Cr levels recorded in this study were higher than those reported by Yi et al. [35] in two fish species (Coreius guichenoti and Leptobotia elongate) where, both the two-fish species had $0.805 \mathrm{mg} / \mathrm{kg}$ ww from the middle and lower reaches of the Yangtze River basin in China. A lower amount of Cr was also recorded by Ahmed et al. [36] on five fish species from Buriganga river, Bangladesh (For example, $\mathrm{C}$ level of $18.84 \pm 1.72 \mathrm{mg} / \mathrm{kg}$ ww in the muscle tissue of Labeo rohita) [37]. Zhang et al. [38] also reported low levels of Cr in Crucian carp $(3.36 \pm 0.0036 \mathrm{mg} / \mathrm{kg})$ from Honghu Lake in China as compared to this study. The THQ of value of $\mathrm{Cr}$ was 42.9138 , hence potentially posing a risk to the consumers of this fish from the lake. This is because $\mathrm{Cr}$ can cause damage to the gastrointestinal, respiratory, and immunological systems, as well as reproductive and developmental problems [7].

Hg: THg concentration in E. paludinosus obtained in this study were higher than those reported by Campbell et al. [39] of $0.081 \mathrm{mg} / \mathrm{kg}$ in the same fish from the same lake. Yi et al. [35] also reported a lower mean concentration of $\mathrm{THg}$ in Eriocheir sinensis from the middle and lower reaches of the Yangtze River basin recording $0.054 \mathrm{mg} / \mathrm{kg}$ ww. Additionally, Stanek et al. [37,40] reported lower values $(0.19 \pm 0.13$ and $0.27 \pm 0.03 \mathrm{mg} / \mathrm{kg} \mathrm{ww}$ ) in the muscles of Chrysichthys nigrodigitatus and Crayfish (Orconectes limosus) from Weija Dam on the Densu River and Lake Gopło, Poland respectively. Our findings were similar to those of Andreji et al. [41] who reported $1.53 \pm 0.80 \mathrm{mg} / \mathrm{kg} \mathrm{ww}$ in the Wels catfish from Lower Nitra River (Slovakia). The THQ value for $\mathrm{Hg}$ was 90.1086 which indicates a huge risk to the consumers as $\mathrm{Hg}$ can cause severe damage to the brain and kidneys [7]. In addition to that, the levels of $\mathrm{Hg}$ were found to be above both of the WHO/FAO and $\mathrm{EU}$ maximum permissible levels making the fish unsafe for consumption

As: The levels of As recorded in this study were high compared to those of Yi et al. [35] in the fish (Rhinogobio typus) reporting a mean concentration of $0.039 \mathrm{mg} / \mathrm{kg} \mathrm{ww}$, from the middle and lower reaches of the Yangtze River basin in China. Lower levels of As were also reported by Ahmed et al. [36] in Labeo rohita from Buriganga river, Bangladesh recording $0.73 \pm 0.03 \mathrm{mg} / \mathrm{kg}$ ww. Gbogbo et al. $[37,38]$ reported lower levels of As in Chrysichthys nigrodigitatus and yellow catfish from Weija Dam on the Densu River and Honghu Lake in China recording (0.37 $\pm 0.24)$ and $(0.0040 \pm 0.0042) \mathrm{mg} / \mathrm{kg}$ ww respectively, with the yellow catfish recording detectable amounts of As among the six fish species in the study. The THQ value of As was 98.5066. Large oral doses of As can cause death while lower doses can cause decreased production of red and white blood cells [7].

\section{Bioconcentration}

The results showed that heavy metal concentrations were higher in E. paludinosus than both in water and sediment. BCF values are important because they serve as both an indication of how many times greater a pollutant is in the biota compared to the environment and also as a means of determining the partitioning between fish and the environment [42]. The BCF values for $\mathrm{As}$ and $\mathrm{Cr}$ could not be calculated for water compared to the fish muscle as they were below detection limits of the instrumentation. The higher concentrations of the heavy metals in the fish muscles compared with the sediment could 
Citation: Ngesa EA, Otachi EO, Kitaka NK (2018) A Little Fish with a High Heavy Metals Burden: The Case of Straightfin Barb, Enteromius paludinosus (Peters 1852) from River Malewa, Naivasha, Kenya. J Environ Anal Toxicol 8: 583. doi: 10.4172/2161-0525.1000583

Page 6 of 7

be explained by the process of sedimentation of the soil particles that are contaminated by the heavy metals from the catchment whereby the heavy metals get absorbed by the fish before the soil particles settle at the bottom of the lake.

\section{Potential of Ligula intestinalis as a bioindicator}

A low number of L. intestinalis infections in E. paludinosus in this study was recorded obtaining 5 of 1307 (prevalence $=0.4 \%$ ) examined individuals infected. Similarly, L. intestinalis prevalence reported by Britton et al. [43] in Lake Naivasha was low, with only 7 of 8665 examined individuals infected between the years 2002-2008 (prevalence $=0.1 \%$ ). The heavy metal with the highest concentration in L. intestinalis was $\mathrm{Pb}$. Compared to the host's muscle in our study, the concentrations of $\mathrm{Hg}, \mathrm{Pb}, \mathrm{Cr}$ and $\mathrm{As}$ in L. intestinalis were 5.1395, 5.8601, 2.1873 and 2.4093 times higher, respectively. From these results, it was evident that $L$. intestinalis has ability to accumulate heavy metals. These results are similar to the findings by Tenora et al. [44] on L. intestinalis from the body cavity of three cyprinid fish species (Abramis brama, Rutilus rutilus, Blicca bjoerkna) which accumulated greater levels of $\mathrm{Pb}, \mathrm{Cr}$ and $\mathrm{Cd}$ than in the fish muscle recording bioaccumualation factors of 15.0, 6.0 and 2.6 respectively. However, Tenora et al. [44] found higher bioaccumulation factors than that of our study. The accumulation ability of $\mathrm{Pb}$ and $\mathrm{Cr}$ by this parasite in the present study was lower than that in the Rastreneobola argentea/L. intestinalis host-parasite system reported by Oyoo-Okoth et al. [45] from Lake Victoria, Kenya. They reported BAF values of 11.6 and 10.8 for $\mathrm{Pb}$ and $\mathrm{Cr}$, respectively with mean concentrations in water of 9.20 and 3.54 for $\mathrm{Pb}$ and $\mathrm{Cr}$ respectively. Elsewhere, cestodes have been found to accumulate heavy metals at concentrations that are orders of magnitude higher than those in the host tissues or the environment [46-48]. For instance, the bioaccumulation factor of a different cestode parasite, Bothriocephalus scorpii from the fish Scophthalmus maximus from the coast of Gdansk, Poland reported very high values than that of its fish host, with values ranging between 60 and 150 for $\mathrm{Pb}$ [49-51]. In as much as other heavy metals burdens have been found in other fish such as O. leucostictus from Lake Naivasha, the bioaccumulation factors of their parasites such as the nematode Contracaecum multipapillatum were not higher than in this study recording $2.94,1.58,1.96$, and 7.04 for $\mathrm{Fe}, \mathrm{Cd}, \mathrm{Cu}$, and $\mathrm{Pb}$ respectively with mean concentrations of $24800,0.34,11.5$ and $12.5 \mathrm{mg} / \mathrm{kg}$ dry weight in the sediment [3]. Thus, in comparison with nematodes, the capacity of the cestode $L$. intestinalis to accumulate these heavy metals is higher. The only limitation of $L$. intestinalis as a bioindicator is its low prevalence and abundance so far experienced during this study.

\section{Conclusion}

The heavy metal concentrations were highest in the parasite followed by the fish muscle tissues, then the sediment and least in water. As and $\mathrm{Cr}$ were below the detection limit of instrumentation in water. The four heavy metals levels in the sediment were below the LEL, TEC, SEL and the Shale values of sedimentary rocks indicating no sign of pollution. $\mathrm{Pb}$ concentrations were high in the fish muscle tissue compared to the other three elements. The levels of $\mathrm{Pb}$ and $\mathrm{Hg}$ in the fish were above the $\mathrm{FAO} / \mathrm{WHO}$ and $\mathrm{EU}$ maximum permissible limits hence not safe for consumption. The THQ values for $\mathrm{As}, \mathrm{Cr}, \mathrm{Pb}$ and $\mathrm{Hg}$ were high and this could put at risk the health of the people that depend on this fish species as their regular source of protein. The four heavy metals showed bioaccumulation factors (BAF) values of $>1$ thus indicating the potential of $L$. intestinalis in accumulation of heavy metals from the host (E. paludinosus) thereby rendering the parasite sensitive metal accumulation biomonitor than its fish host

\section{Acknowledgements}

We thank the Rotary Club of Vienna (RCV) for funding this study through a master's fellowship awarded at Egerton University. Many thanks also go to Egerton University for providing the laboratory space and equipment as well as the joint Limnology and Wetland Management (LWM) program for providing the laboratory equipment, Lake Naivasha fishermen and the technical team (including my colleagues) that helped in obtaining and processing of the fish samples. We also thank Mr. Andrew Kulecho and the technical team from The Lake Nakuru Water Quality Testing Laboratory in assisting in the analysis of the samples and also everyone else involved in making this study a success. All the fish used in the research were treated and killed humanely according to Egerton University guidelines.

\section{References}

1. Ochieng EZ, Lalah JO, Wandiga SO (2007) Analysis of heavy metals in water and surface sediment in five rift valley lakes in Kenya for assessment of recent increase in anthropogenic activities. Bulletin of Environmental Contamination and Toxicology 79: 570-576.

2. Schmitt D, Saravia F, Frimmel FH, Schuessler W (2003) NOM-facilitated transport of metal ions in aquifers: importance of complex-dissociation kinetics and colloid formation. Water Research 37: 3541-3550.

3. Otachi EO, Körner W, Avenant-Oldewage A, Fellner-Frank C, Jirsa F (2014) Trace elements in sediments, blue spotted tilapia Oreochromis leucostictus (Trewavas, 1933) and its parasite Contracaecum multipapillatum from Lake Naivasha, Kenya, including a comprehensive health risk analysis. Environmental Science and Pollution Research 21: 7339-7349.

4. PlessI C, Otachi EO, Körner W, Avenant-Oldewage A, Jirsa F (2017) Fish as bioindicators for trace element pollution from two contrasting lakes in the eastern rift valley, Kenya: Spatial and temporal aspects. Environmental Science and Pollution Research 24: 19767-19776.

5. Lim PE, Lee CK, Din Z (1995) Accumulation of heavy metals by cultured oysters from Merbok Estuary, Malaysia. Marine pollution bulletin 31: 420-423.

6. Van der Putte I, Pårt P (1982) Oxygen and chromium transfer in perfused gills of rainbow trout (Salmo gairdneri) exposed to hexavalent chromium at two different $\mathrm{pH}$ levels. Aquatic Toxicology 2: 31-45.

7. McCartor A, Becker D (2013) Blacksmith Institute's world worst pollution problems report 2010, top six toxic threats. Blacksmith Institute, New York, USA

8. Mutia TM, Virani MZ, Moturi WN, Muyela B, Mavura WJ, et al. (2012) Copper lead and cadmium concentrations in surface water, sediment and fish, $C$ Carpio, samples from Lake Naivasha: effect of recent anthropogenic activities. Environmental Earth Sciences, 67: 1121-1130.

9. Yang Y, Wei L, Cui L, Zhang M, Wang J (2017) Profiles and risk assessment of heavy metals in Great Rift Lakes, Kenya. Clean-Soil, Air, Water, p: 45.

10. Turekian KK, Wedepohl KH (1961) Distribution of the elements in some major units of the earth's crust. Geological Society of America Bulletin 72: 175-192.

11. FAO (Food and Agriculture Organization) / WHO (World Health Organization) (2011) Report of the fifth session of the Codex Committee on contaminants in foods. Codex Alimentarius Commission, Rome, Italy.

12. Tweddle D, Skelton PH (2008) New species of' Barbus' and Labeobarbus (Teleostei: Cyprinidae) from the South Rukuru River, Malawi, Africa. Smithiana Bulletin 25-39.

13. Gaudet JJ, Melack JM (1981) Major ion chemistry in a tropical African lake basin. Freshwater Biology 11: 309-333.

14. Hickley P, Bailey R, Harper DM, Kundu R, Muchiri M, et al. (2002) The status and future of the Lake Naivasha fishery, Kenya. Hydrobiologia 488: 181-190

15. Njiru J, Morara G, Waithaka E, Mugo J (2015) Fish kills in Lake Naivasha, Kenya: What was the probable cause? International Journal of Fisheries and Aquatic Studies 3: 179-184.

16. Kamau JN, Gachanja A, Ngila C, Kazungu JM, Zhai M (2008) Anthropogenic and seasonal influences on the dynamics of selected heavy metals in Lake Naivasha, Kenya. Lakes \& Reservoirs: Research \& Management 13: 145-154.

17. Kitaka N, Harper DM, Mavuti KM, (2002) Phosphorus inputs to Lake Naivasha Kenya, from its catchment and the trophic state of the lake. In Lake Naivasha, Kenya. Hydrobiologia 488: 73-80.

18. Van Oel PR, Mulatu DW, Odongo VO, Meins FM, Hogeboom RJ, et al. (2013) 
Citation: Ngesa EA, Otachi EO, Kitaka NK (2018) A Little Fish with a High Heavy Metals Burden: The Case of Straightfin Barb, Enteromius paludinosus (Peters 1852) from River Malewa, Naivasha, Kenya. J Environ Anal Toxicol 8: 583. doi: 10.4172/2161-0525.1000583

The effects of groundwater and surface water use on total water availability and implications for water management: the case of Lake Naivasha, Kenya. Water resources management 27: 3477-3492.

19. LNRA: Lake Naivasha Riparian Association. 1999. Lake Naivasha Management Plan, pp. 77 Naivasha, Kenya. In the Kenya gazette October 2004, Kenya Government Press, Nairobi, Kenya.

20. Ndungu J, Augustijn DCM, Hulscher SJMH, Kitaka N, Mathooko J (2013) Spatio temporal variations in the trophic status of Lake Naivasha, Kenya. Lakes and Reseviours: Research and Management 18: 317-328.

21. Odongo VO, Tol C, Oel PR, Meins FM, Becht R, et al. (2015) Characterisation of hydroclimatological trends and variability in the lake Naivasha basin, Kenya. Hydrological processes 29: 3276- 3293

22. Harper DM, Morrison EH, Macharia, MM, Mavuti KM, Upton, C (2011) Lake Naivasha, Kenya: ecology, society and future. Freshwater Reviews 4: 89-114.

23. Florio D, Gustinelli A, Caffara M, Turci F, Quaglio F, et al. (2009) Veterinary and public health aspects in tilapia (Oreochromis niloticus niloticus) aquaculture in Kenya, Uganda and Ethiopia. Ittiopatologia 6: 51-93.

24. APHA (2012) Standard Methods for the Examination of Water and Wastewater 22nd edn. American Public Health Association Publishers, Washing DC, USA.

25. Abel PD (1989) Pollutant toxicity to aquatic animals-Methods of study and their applications. Reviews on environmental health 8: 119-156.

26. Drexler J, Fisher N, Henningsen G, Lanno R, McGeer J, et al. (2003) Issue pape on the bioavailability and bioaccumulation of metals. In US Environmental Protection Agency, Risk Assessment Forum, Washington, DC, USA.

27. USEPA (United States Environmental Protection Agency) (2012) Mid-Atlantic Risk Assessment. https://www.epa.gov/risk/human-health-risk-assessment Accessed on 24 April 2018.

28. KMFRI (2017) Kenya's Aquaculture Brief 2017: Status, Trends, Challenges and Future Outlook. Kenya Marine and Fisheries Research Institute, Mombasa, Kenya.

29. USEPA (United States Environmental Protection Agency) (2017) Regional Screening Levels (RSLs) - User's Guide (November 2017). https://www.epa. gov/risk/regional-screening-levels-rsls-users-guide Accessed on 15 May 2018.

30. Walpole SC, Prieto-Merino D, Edwards P, Cleland J, Stevens G, et al. (2012) The weight of nations: an estimation of adult human biomass. BMC Public Health 12: 439.

31. Wanjau RN, Njogu PM, Keriko JM, Kitetu JJ (2014) Distribution of heavy metals in various lake matrices; water, soil, fish and sediments: A case study of the lake Naivasha Basin, Kenya.

32. Ogendi GM, Maina GM, Mbuthia JW, Koech HK, Ratemo CM, et al. (2014) Heavy metal concentrations in water, sediments and common carp (Cyprinus carpio) fish species from Lake Naivasha, Kenya. Research Journal of Environmental and Earth Sciences 6: 416-423.

33. WHO (2011) Guidelines for drinking water quality. 4th edn. World Health Organization, Geneva.

34. EU (2006) Commission Regulation (EC) No 1881/2006: Setting maximum levels for certain contaminants in foodstuffs.

35. Yi Y, Yang Z, Zhang S (2011) Ecological risk assessment of heavy metals in sediment and human health risk assessment of heavy metals in fishes in the middle and lower reaches of the Yangtze River basin. Environmental Pollution 159: 2575-2585.

36. Ahmed MK, Baki MA, Kundu GK, Islam MS, Islam MM, et al. (2016) Human health risks from heavy metals in fish of Buriganga river, Bangladesh. Springer Plus 5: 1697.
37. Gbogbo F, Arthur-Yartel A, Bondzie JA, Dorleku WP, Dadzie S, et al. (2018) Risk of heavy metal ingestion from the consumption of two commercially valuable species of fish from the fresh and coastal waters of Ghana. PloS ONE 13: e0194682.

38. Zhang J, Zhu L, Li F, Liu C, Yang Z, et al. (2017) Heavy metals and metalloid distribution in different organs and health risk assessment for edible tissues of fish captured from Honghu Lake. Oncotarget 8: 101672- 101685

39. Campbell LM, Osano O, Hecky E, Dixon DG (2003) Mercury in fish from three rift valley lakes (Turkana, Naivasha and Baringo), Kenya, East Africa. Environmental Pollution 125: 281-286.

40. Stanek M, Dąbrowski J, Różański S, Janicki B, Długosz J (2017) Heavy Metals Bioaccumulation in Tissues of Spiny-Cheek Crayfish (Orconectes limosus) from Lake Gopło: Effect of Age and Sex. Bulletin of Environmental Contamination and Toxicology 98: 740-746.

41. Andreji J, Stranai I, Massanyi P, Valent M (2006) Accumulation of some metals in muscles of five fish species from lower Nitra River. Journal of Environmental Science and Health Part A 41: 2607-2622.

42. McGeer JC, Brix KV, Skeaff JM, Deforest DK, Brigham SI, et al. (2003) Inverse relationship between bioconcentration factor and exposure concentration for metals: Implications for hazard assessment of metals in the aquatic environment. Environmental Toxicology and Chemistry 22: 1017-1037.

43. Britton JR, Jackson MC, Harper DM (2009) Ligula intestinalis (Cestoda: Diphyllobothriidae) in Kenya: a field investigation into host specificity and behavioural alterations. Parasitology, 136: 1367-1373.

44. Tenora F, Baruš V, Kracmars S, Dvocarek J (2000) Concentration of some heavy metals in Ligula intestinalis plerecercoides, cestode and Philometra ovata, nematodes compared to some of their hosts, Osteichthyes. Helminthologia 37: 15-18.

45. Oyoo-Okoth E, Wim A, Osano O, Kraak MH, Ngure V, et al. (2010) Use of the fish endo-parasite Ligula intestinalis (L., 1758) in an intermediate cyprinid host (Rastreneobola argentea) for biomonitoring heavy metal contamination in Lake Victoria, Kenya. Lakes and Reservoirs: Research and Management 15: $63-73$.

46. Sures B, Steiner W, Rydlo M, Taraschewski H (1999) Concentrations of 17 elements in the zebra mussel (Dreissena polymorpha), in different tissues of perch (Perca fluviatilis), and in perch intestinal parasites (Acanthocephalus lucii) from the subalpine lake Mondsee,Austria. Environmental Toxicology and Chemistry 18: 2574-2579.

47. Dvoracek J, Tenora F, Barus V, Kracmar S (2000) Concentrations of some heavy metals in Ligula intestinalis plerocercoids (Cestoda) and Philometra ovata (Nematoda) compared to some their hosts (Osteichthyes). Helminthologia 37: 15-18.

48. Jirsa F, Leodolter-Dvorak M, Krachler R (2008) Heavy metals in the nase Chondrostomanasus, (L. 1758), and its intestinal parasite Caryophyllaeus laticeps, (Pallas 1781) from Austrian rivers, Bioindicative aspects. Archives of Environmental Contamination and Toxicology 55: 619-626.

49. Sures B, Taraschewski H, Rokicki J (1997) Lead and cadmium content of two cestodes, Monobothrium wageneri and Bothriocephalus scorpii, and their fish hosts. Parasitology Research 83: 618- 623.

50. KEBS (Kenya Bureau of Standards) (2014) Kenya Standard Potable water KS EAS 12: 2014, ICS 13.060.20. Nairobi, Kenya.

51. Buchman MF (2008) NOAA Screening Quick Reference Tables, NOAA OR\&R Report 08-1, Seattle WA, Office of Response and Restoration Division, National Oceanic and Atmospheric Administration. 